\title{
GERIAMŲJŲ D VITAMINO PREPARATŲ TERAPINIS POVEIKIS PACIENTAMS, SERGANTIEMS ATOPINIU DERMATITU
}

\author{
Evelina Petruškevičiūtė ${ }^{1}$, Inga Kisielienè $\dot{2}^{2}$ \\ ${ }^{1}$ Vilniaus universitetas, Medicinos fakultetas, \\ ${ }^{2}$ Vilniaus universitetas, Medicinos fakultetas, Klinikinès medicinos institutas, Infekciniu ligu ir \\ dermatovenerologijos klinika, Vilniaus universiteto ligonine Santaros klinikos, Pediatrijos centras
}

Raktažodžiai: atopinis dermatitas, D vitamino papildai, atopinè egzema, D vitaminas.

\begin{abstract}
Santrauka
Tikslas - išanalizuoti ir apibendrinti klinikines studijas, tiriančias geriamujų $\mathrm{D}$ vitamino papildų terapini poveiki atopine egzema sergantiems pacientams. Tyrimo metodas - sisteminė literatūros apžvalga. Mokslinès literatūros paieška atlikta naudojantis PubMed ir UpToDate medicinos duomenų bazèmis. Buvo peržiūrètos 2015-2021 metais anglų kalba išspausdintos publikacijos, bei šiu publikacijų šaltiniai. Rezultatai. Mokslinèje literatūroje daugeja ịrodymų, kad yra ryšys tarp D vitamino stokos ir egzemos išsivystymo. Lyginant sveikus tiriamuosius, bei pacientus, sergančius atopine egzema, pastebèta, kad atopiniu dermatitu sergančių pacientų 25(OH)D koncentracija kraujo serume yra statistiškai reikšmingai mažesnè. Mažejant D vitamino koncentracijai kraujo serume, didèja AD sunkumas pagal SCORAD indeksą. Apžvelgę naujausių klinikinių tyrimų rezultatus, galime pastebèti tendenciją, kad peroralinè D vitamino terapija teigiamai veikia pacientų, sergančių atopine egzema, odos būklę. Išvados. Nors klinikinių tyrimų rezultatai vis dar yra nevienareikšmiai, daugejja duomenų, kad peroralinè D vitamino terapija mažina atopinio dermatito simptomus bei apsaugo nuo S.aureus kolonizacijos odoje. Kadangi klinikinių studijų skirtinga metodika, norint sukaupti pakankamai mokslu pagrịstų ịrodymų šia tema, reikalingi struktūrizuoti, daugiacentriniai, didelès apimties klinikiniai tyrimai.
\end{abstract}

\section{Ivadas}

Atopinis dermatitas arba egzema yra lètinè uždegiminè odos liga, diagnozuojama iki 20 proc. vaikų visame pasaulyje. Augant simptomai palaipsniui mažèja, tačiau apie 5 proc. suaugusiujų liga išlieka persistuojanti [1]. Pastaraisiais metais stebimas sergamumo atopine egzema didejjimas visose pacientų amžiaus grupèse [2]. Atopinès egzemos patogenezè yra sudètinga ir kompleksinè - manoma, kad ligos išsivystymui svarbus paveldimumas, sutrikusi odos barjerinè funkcija, pakitęs organizmo imuninis atsakas bei išorès veiksniai [3]. Nagrinejjant atopinio dermatito paplitimą buvo pastebėta, kad daugiau šios ligos atvejų užregistruojama šiaurinèse geografinèse platumose, kur mažesnè saulès ekspozicija, o pacientams egzemos simptomai ịprastai paūmèja žiemos laikotarpiu [4]. Taip kilo hipotezè, kad ne tik klimato pokyčiai, bet ir D vitamino trūkumas gali būti susijęs su atopinès egzemos vystymusi, o D vitamino papildai galètų būti naudojami atopinio dermatito gydymui. Pastaraji dešimtmetị pradètas tyrinèti peroralinių $\mathrm{D}$ vitamino preparatų terapinis poveikis egzema sergantiems pacientams, siekiant išsiaiškinti jų efektyvumą ir galimybę įtraukti ị atopinio dermatito gydymo rekomendacijas.

Tyrimo tikslas - apžvelgti naujausias publikacijas, aprašančias $\mathrm{D}$ vitamino vaidmeni atopinio dermatito patogenezèje bei tiriančias peroralinès $\mathrm{D}$ vitamino terapijos poveikį atopine egzema sergantiems pacientams, išnagrinèti rezultatus ir pateikti išvadas, remiantis moksline literatūra.

\section{Tyrimo medžiaga ir metodai}

Mokslinès literatūros paieška atlikta naudojantis PubMed ir UpToDate medicinos duomenų bazèmis, ịvedus reikšminius žodžius ir jų derinius: atopic dermatitis, vitamin D supplementation, atopic eczema, vitamin D. Buvo peržiūrètos 2015-2021 metais anglų kalba išspausdintos publikacijos ir šiu publikacijų šaltiniai, iš kurių atrinktos ir išanalizuotos 25 publikacijos. İ apžvalginị straipsnị įtraukti atsitiktinių imčių, dvigubai akli, placebo kontroliuojami klinikiniai tyrimai, atvejo ir kontrolès klinikiniai tyrimai, kohortiniai klinikiniai tyrimai bei sisteminès literatūros apžvalgos. 


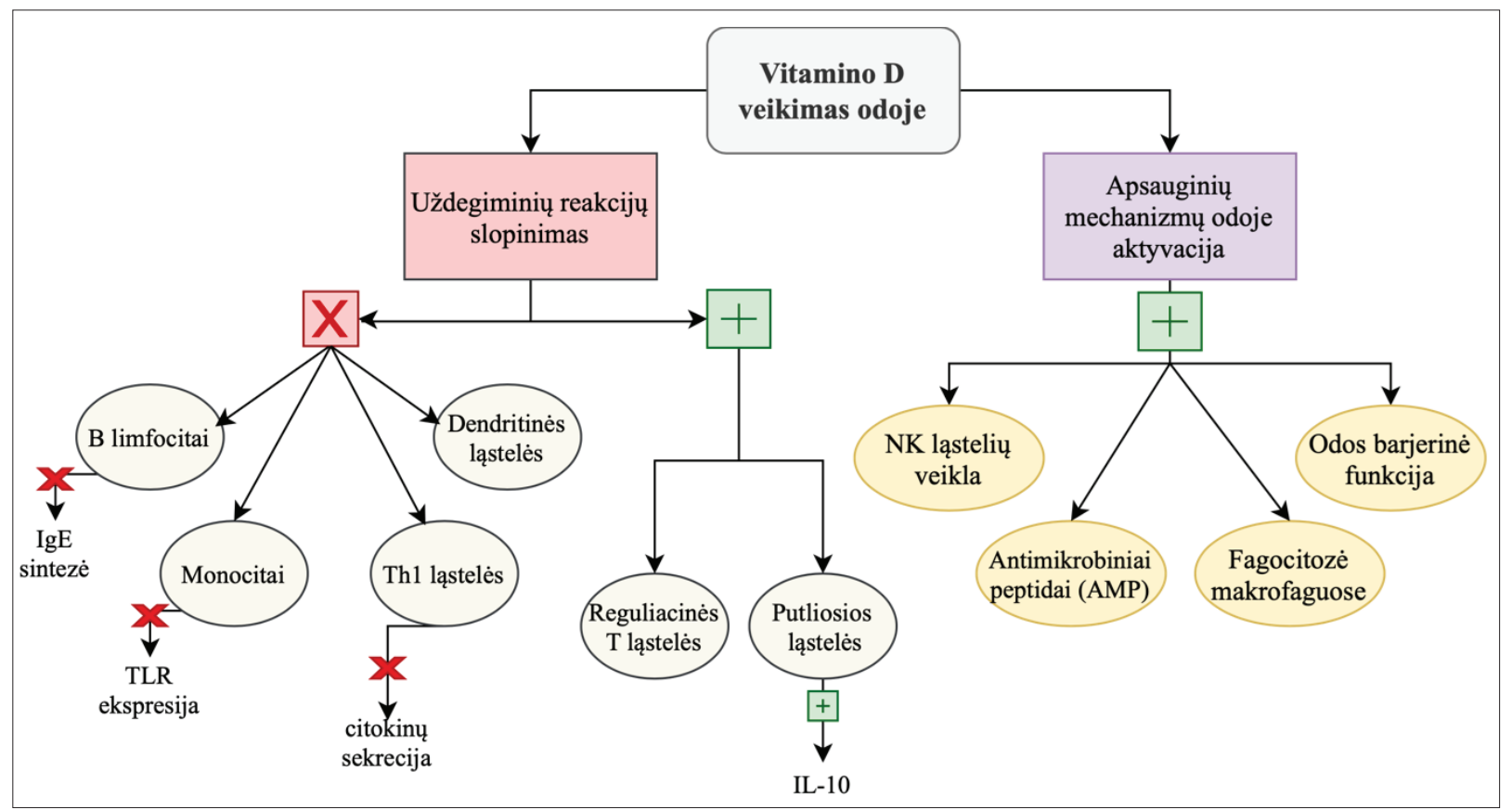

1 pav. D vitamino poveikis imuninei sistemai ir odos barjerinei funkcijai

Ženklas ,,+" nurodo aktyvacijos, o ,, $\mathbf{x}$ " inhibicijos procesus.

\section{Tyrimo rezultatai ir jų aptarimas}

Mokslinèje literatūroje daugèja ịrodymų, kad yra ryšys tarp D hipovitaminozès ir egzemos išsivystymo. Manoma, kad nepakankama D vitamino koncentracija naujagimiu kraujyje asocijuojasi su didesniu sergamumu atopinemis ligomis ankstyvoje vaikystėje [5,6]. Mokslinès literatūros duomenimis, esant mažesniam D vitamino kiekiui kraujo serume, nustatomas didesnis AD sunkumas pagal SCORAD indeksą [7]. Lyginant sveikus tiriamuosius ir sergančiuosius atopine egzema, pastebèta, kad atopiniu dermatitu sergančiu pacientų 25(OH)D koncentracija kraujo serume yra statistiškai reikšmingai mažesnė už sveikų tiriamųų [8]. Tikslus D vitamino veikimo mechanizmas atopinio dermatito patogenezèje dar nèra iki galo ištyrinètas, tačiau atliktų klinikinių studijų rezultatai parodè, kad jis atlieka protekcinę funkciją, padèdamas palaikyti sveiką odos barjerą ir normalią imuninès sistemos veiklą [9]. Tai pagrindžia $\mathrm{D}$ vitamino receptorių (VDR) pasireiškimas keratinocituose bei ịvairiose imuninès sistemos ląstelèse: T limfocituose, B limfocituose, neutrofiluose, makrofaguose [10].

D vitamino poveikis imuninei sistemai ir odos barjerinei funkcijai pavaizduotas 1 paveiksle (adaptuota pagal S. Quirk ir kt. [11]). D vitaminas aktyvina apsauginius mechanizmus odoje prieš įvairius mikroorganizmus bei inhibuoja uždegimini igimto ir igyto imuniteto atsaką, taip slopindamas uždegiminius procesus odoje [12]. Biologiškai aktyvus D vitamino metabolitas kalcitriolis skatina keratinocitus išskirti antimikrobinius peptidus (AMP), tokius kaip katelicidinas ir $\beta \beta$ - defensinai, taip sustiprindamas vietinị odos imuniteta prieš mikroorganizmus, pavyzdžiui, prieš S.aureus [13]. D vitaminas padeda palaikyti normalią odos barjerinę funkcija, reguliuodamas odos baltymu ir lipidu sinteze, bei skatindamas keratinocitu proliferaciją [14]. Kalcitriolis aktyvina fagocitozę makrofaguose bei indukuoja NK ląstelių veiklą [15]. D vitaminas slopina uždegimines reakcijas keliais būdais: inhibuodamas imunoglobulino E (IgE) sintezę B limfocituose, slopindamas transmembraninių atpažinimo receptorių (TLR) ekspresiją monocituose, skatindamas uždegimą slopinančio citokino IL-10 išsiskyrimą iš putliujų ląstelių, inhibuodamas dendritinių ląsteliu aktyvaciją ir Th1 ląstelių veiklą, bei aktyvindamas reguliacines T ląsteles [15].

Išaiškinus biologinius kalcitriolio veikimo mechanizmus odoje ir imuninèje sistemoje buvo pasiūlyta, kad D vitamino papildai galètų būti naudojami atopinio dermatito gydymui [16]. Imta manyti, kad fototerapija efektyviai sumažina egzemos simptomus ne tik dèl ultravioletinių spindulių tiesioginio poveikio uždegiminèms ląstelèms odoje bei antibakterinio poveikio tokiems mikroorganizmams, kaip auksinis stafilokokas (S.aureus), bet ir dèl suaktyvèjusios D vitamino sintezès epidermyje [17]. Iki šiol nèra surinkta pakankamai duomenų, galinčių patvirtinti arba paneigti šias hipotezes, atliktų tyrimų rezultatai yra nevienareikšmiai. Šiame darbe buvo apžvelgtos 
naujausios, per pastaruosius penkerius metus atliktos klinikinès studijos, tiriančios D vitamino papildų efektyvumą, gydant sergančiuosius atopine egzema (1 lentelè).

Apžvelgę naujausių klinikinių tyrimų rezultatus, galime pastebèti tendenciją, kad peroralinè D vitamino terapija teigiamai veikia pacientų, sergančių atopine egzema, odos būklę [18,20-25]. Daugumos tyrimų pabaigoje SCORAD arba EASI indeksas statistiškai reikšmingai labiau sumažèjo grupèje, gavusioje D vitamino papildų, lyginant su placebo grupe $[18,20,21]$. Tik vieni tyrejjai nenustate statistiškai reikšmingo ryšio tarp tiriamujų grupių [19]. Klinikinių studijų rezultatai parodé, kad geriamieji $\mathrm{D}$ vitamino preparatai galimai sumažina S.aureus kolonizaciją odoje ir taip palengvina atopinio dermatito eigą [20]. L. Albenali ir kiti [25] nustate, kad peroralinė D vitamino terapija pagerina ne tik atopiniu dermatitu, bet ir herpetine egzema sergančių pacientų odos būklę. Tyrèjų atlikta klinikinè studija parodè, kad geriamieji D vitamino papildai padidina antimikrobinio peptido LL-37 gamybą odoje, o šis yra svarbus odos epitelizacijai bei vietinei odos apsaugai nuo patogeninių mikroorganizmų. Vienas tyrimas pabrěžè, kad geriamieji $\mathrm{D}$ vitamino preparatai gali būti naudojami kaip efektyvi adjuvantinè terapija pacientams, gydomiems nuo atopinès egzemos pagal naujausias gydymo rekomendacijas [22].

\section{Išvados}

1. Atopinio dermatito patogenezejje D vitaminas atlieka apsauginę funkciją, padedamas palaikyti odos barjerinę funkciją ir normalią imuninès sistemos veiklą.

2. Daugeja duomenų, kad peroralinė D vitamino terapija mažina atopinès egzemos simptomus ir apsaugo nuo S.aureus kolonizacijos odoje, todèl D vitamino papildai galètų būti

1 lentelè. Klinikiniai tyrimai, nagrinejjantys peroralinių D vitamino papildų terapinị poveikị atopine egzema sergantiems pacientams, publikuoti 2015-2021 metais.

$A D$ - atopinis dermatitas.

\begin{tabular}{|c|c|c|c|c|}
\hline Autoriai & Tyrimo tikslas & Tyrimo metodika & Tiriamieji & Tyrimo rezultatai \\
\hline $\begin{array}{l}\text { N. Mansour } \\
\text { ir kiti, } 2020 \\
{[18]}\end{array}$ & $\begin{array}{l}\text { Nustatyti D vitamino pa- } \\
\text { pildų terapinị poveiki paci- } \\
\text { entams, sergantiems sunkios } \\
\text { eigos atopiniu dermatitu. } \\
\text { Rezultatai vertinami pagal } \\
\text { EASI indeksa }\end{array}$ & $\begin{array}{l}\text { Klinikinis atsitiktinių imčiu tyrimas. } \\
\text { Dvigubai aklas, placebo kontroliuo- } \\
\text { jamas tyrimas. } \\
\text { Buvo skiriami peroraliniai D vita- } \\
\text { mino } 3 \text { papildai } 1600 \text { IU/d. Tyrimas } \\
\text { truko } 3 \text { menesius }\end{array}$ & $\begin{array}{l}\text { Pacientai, sergantys AD } \\
(\mathrm{n}=92) . \\
\text { n-vit.D }=47 \\
\text { n-placebo }=45 \\
\text { Amžius: } 5-16 \text { metur }\end{array}$ & $\begin{array}{l}\text { Tyrimo pabaigoje vidutinis ir procen- } \\
\text { tinis EASI indeksas buvo reikšmin- } \\
\text { gai mažesnis } D \text { vitamino papildais } \\
\text { gydytiems pacientams, lyginant su } \\
\text { placebo grupe }(p=0.035 ; p=0.039)\end{array}$ \\
\hline $\begin{array}{l}\text { I. Lara-Corrales } \\
\text { ir kiti, } \\
2019[19]\end{array}$ & $\begin{array}{l}\text { Nustatyti D vitamino pa- } \\
\text { pildų terapinị poveikị pa- } \\
\text { cientams, sergantiems ato- } \\
\text { piniu dermatitu. Rezultatai } \\
\text { vertinami pagal SCORAD } \\
\text { indeksą }\end{array}$ & $\begin{array}{l}\text { Klinikinis atsitiktiniu imčiu tyrimas. } \\
\text { Dvigubai aklas, placebo kontroliuo- } \\
\text { jamas tyrimas. } \\
\text { Buvo skiriami peroraliniai D vita- } \\
\text { mino } 3 \text { papildai } 2000 \mathrm{IU} / \mathrm{d} \text {. Tyrimas } \\
\text { truko } 3 \text { ménesius }\end{array}$ & $\begin{array}{l}\text { Pacientai, sergantys AD } \\
(\mathrm{n}=45) . \\
\text { n-vit.D }=21 \\
\text { n-placebo }=24 \\
\text { Amžius: } 0-18 \text { metu }\end{array}$ & $\begin{array}{l}\text { Vidutinis SCORAD indekso pokytis } \\
\text { per } 3 \text { ménesius statistiškai reikšmin- } \\
\text { gai nesiskyre tarp tiriamujų grupių } \\
(p=0,7) \text {. }\end{array}$ \\
\hline $\begin{array}{l}\text { M. Udompataikul } \\
\text { ir kiti, } 2015 \text { [20] }\end{array}$ & $\begin{array}{l}\text { Nustatyti peroralinių D } \\
\text { vitamino papildų terapini } \\
\text { poveiki atopiniu dermatitu } \\
\text { sergantiems pacientams, } \\
\text { kurių oda yra kolonizuota } \\
\text { S.aureus. Rezultatai verti- } \\
\text { nami pagal SCORAD in- } \\
\text { deksą }\end{array}$ & $\begin{array}{l}\text { Klinikinis atsitiktinių imčių tyrimas. } \\
\text { Dvigubai aklas, placebo kontroliuo- } \\
\text { jamas tyrimas. } \\
\text { Buvo skiriami peroraliniai D vita- } \\
\text { mino } 3 \text { papildai } 2000 \text { IU/d. Tyrimas } \\
\text { truko } 1 \text { mėnesi }\end{array}$ & $\begin{array}{l}\text { Pacientai, sergantys AD } \\
(\mathrm{n}=24) \\
\mathrm{n} \text {-vit.D }=12 \\
\text { n-placebo }=12 \\
\text { Amžius: } 1-18 \text { metu }\end{array}$ & $\begin{array}{l}\text { Tyrimo pabaigoje SCORAD indeksas } \\
\text { statistiškai reikšmingai labiau suma- } \\
\text { žejo grupeje, gavusioje D vitamino } \\
\text { papildų, lyginant su placebo grupe } \\
\text { (p=0.022). Nustatyta atvirkštinè ko- } \\
\text { reliacija tarp } 25(\mathrm{OH}) \mathrm{D} \text { koncentraci- } \\
\text { jos kraujo serume ir } \text { S.aureus odos } \\
\text { kolonizacijos }\end{array}$ \\
\hline $\begin{array}{l}\text { P. Filippo } \\
\text { ir kiti, 2015 [21] }\end{array}$ & $\begin{array}{l}\text { Nustatyti D vitamino pa- } \\
\text { pildų terapini poveiki paci- } \\
\text { entams, sergantiems atopiniu } \\
\text { dermatitu, îvertinant rezulta- } \\
\text { tus pagal SCORAD indeksą } \\
\text { ir citokinų IL- } 2 \text {, IL-4, IL-6, } \\
\text { IFN- } \gamma \text {, TNF- } \alpha \text { pokyti kraujo } \\
\text { serume }\end{array}$ & $\begin{array}{l}\text { Atvejo ir kontrolès tyrimas. } \\
\text { Pacientams buvo skiriami perorali- } \\
\text { niai D vitamino } 3 \text { papildai } 1000 \mathrm{IU} / \mathrm{d} \text {. } \\
\text { Tyrimas truko } 3 \text { ménesius }\end{array}$ & $\begin{array}{l}\text { AD sergantys vaikai } \\
(\mathrm{n}=39) \text { bei kontroline } \\
\text { grupé, sudaryta iš sveikų } \\
\text { vaikų }(\mathrm{n}=20) \text {. } \\
\text { Amžius: } 4 \pm 3.15 \text { metų }\end{array}$ & $\begin{array}{l}\text { Po } 3 \text { mènesių peroralinès } \mathrm{D} \text { vitamino } \\
\text { terapijos buvo nustatytas statistiškai } \\
\text { reikšmingas tiek SCORAD indekso, } \\
\text { tiek citokinų kiekio sumažėjimas vai- } \\
\text { kams, sergantiems } A D(p<0.05)\end{array}$ \\
\hline $\begin{array}{l}\text { K. Sánchez- } \\
\text { Armendáriz } \\
\text { ir kiti, } 2018 \text { [22] }\end{array}$ & $\begin{array}{l}\text { Nustatyti, ar peroraliniai D } \\
\text { vitamino papildai turi tei- } \\
\text { giamą poveikị, naudojant } \\
\text { juos kaip adjuvantinę tera- } \\
\text { piją AD pacientams, gydo- } \\
\text { miems pagal rekomenda- } \\
\text { cijas }\end{array}$ & $\begin{array}{l}\text { Klinikinis atsitiktinių imčių tyrimas. } \\
\text { Dvigubai aklas, placebo kontroliuo- } \\
\text { jamas tyrimas. } \\
\text { Buvo skiriami peroraliniai D vita- } \\
\text { mino } 3 \text { papildai } 5000 \mathrm{IU} / \mathrm{d} \text {. Tyrimas } \\
\text { truko } 3 \text { menesius }\end{array}$ & $\begin{array}{l}\text { AD pacientai, gydomi } \\
\text { vietiniais gliukokorti- } \\
\text { koidais bei emolientais } \\
(\mathrm{n}=65) . \\
\mathrm{n} \text {-vit. } \mathrm{D}=33 \\
\mathrm{n} \text {-placebo }=32\end{array}$ & $\begin{array}{l}\text { Tyrimo pabaigoje SCORAD indeksas } \\
\text { reikšmingai sumažejo tiems pacien- } \\
\text { tams, kurių } 25(\mathrm{OH}) \mathrm{D} \text { koncentracija } \\
\text { kraujo serume buvo }>50 \mathrm{nmol} / 1 \text {, ne- } \\
\text { priklausomai nuo to, kurioje grupejje } \\
\text { buvo tiriamasis }\end{array}$ \\
\hline
\end{tabular}




\begin{tabular}{|c|c|c|c|c|}
\hline $\begin{array}{l}\text { K. Tsotra } \\
\text { ir kiti, } 2017 \text { [23] }\end{array}$ & $\begin{array}{l}\text { Nustatyti D vitamino pa- } \\
\text { pildų terapinị poveikị vai- } \\
\text { kams, sergantiems atopiniu } \\
\text { dermatitu, ivertinant rezulta- } \\
\text { tus pagal SCORAD indeksą }\end{array}$ & $\begin{array}{l}\text { Eksperimentinis intervencinis klini- } \\
\text { kinis tyrimas. } \\
\text { Buvo skiriama } 1200 I U / d \text { geriamujų } \\
\text { D3 vit. papildu pacientams, sergan- } \\
\text { tiems lengvos eigos AD (SCORAD } \\
<40 \text { ) ir } 2400 I U / d \text { D3 vit. pacien- } \\
\text { tams, sergantiems sunkios eigos AD } \\
(\text { SCORAD }>40) \text {. Tyrimas truko } 2 \\
\text { ménesius }\end{array}$ & $\begin{array}{l}\text { Vaikai, sergantys AD } \\
(\mathrm{n}=50) \text {, pagal SCORAD } \\
\text { indeksą buvo suskirstyti } \\
\text { i dvi grupes: lengvos } \\
\text { eigos AD (SCORAD } \\
<40) \text { ir sunkios eigos AD } \\
(\text { SCORAD }>40)\end{array}$ & $\begin{array}{l}\text { Tyrimo pradžioje SCORAD indeksas } \\
\text { statistiškai reikšmingai skyrèsi tarp } \\
\text { tiriamujjų grupių ( }<<0,001) \text {. Po } 20 \\
\text { dienų geriamujų } \mathrm{D} \text { vitamino papildų } \\
\text { skyrimo, SCORAD indekso skirtu- } \\
\text { mas tarp tiriamujų grupių išnyko (p } \\
=0,65) \text { ir išliko statistiškai nereikš- } \\
\text { mingas } 45(\mathrm{p}=0,61) \text { ir } 60(\mathrm{p}=0,48) \\
\text { tyrimo dieną. Buvo stebimas ryškus } \\
\text { AD simptomų sumažejimas sunkios } \\
\text { eigos AD sergantiems vaikams }\end{array}$ \\
\hline $\begin{array}{l}\text { R. Imoto } \\
\text { ir kiti, } 2021 \text { [24] }\end{array}$ & $\begin{array}{l}\text { Nustatyti D vitamino pa- } \\
\text { pildų terapinị poveikị vai- } \\
\text { kams, sergantiems atopiniu } \\
\text { dermatitu, ivertinant rezulta- } \\
\text { tus pagal SCORAD indeksą }\end{array}$ & $\begin{array}{l}\text { Eksperimentinis intervencinis klini- } \\
\text { kinis tyrimas. } \\
\text { Pacientams, kuriems buvo nustatytas } \\
\text { D vit. nepakankamumas }(21-29 \mathrm{ng} / \\
\text { ml), } 12 \text { sav. buvo skiriami geriamieji } \\
\text { D3 vit. papildai } 15000 \mathrm{IU} / \mathrm{d} \text {. Pacien- } \\
\text { tams, kuriems buvo nustatytas D vit. } \\
\text { trūkumas }(<21 \mathrm{ng} / \mathrm{ml}), 4 \text { sav. buvo } \\
\text { skiriami geriamieji D3 vit. papildai } \\
\text { 50000IU/d ir } 15000 \mathrm{IU} / \mathrm{d} \text { likusias } 8 \\
\text { sav. }\end{array}$ & $\begin{array}{l}\text { 1-14 metų amžiaus AD } \\
\text { sergantys vaikai }(n=152)\end{array}$ & $\begin{array}{l}\text { Po } 3 \text { mènesių peroralinès } D \text { vitamino } \\
\text { terapijos buvo nustatytas statistiškai } \\
\text { reikšmingas SCORAD indekso su- } \\
\text { mažèjimas }(p<0.001)\end{array}$ \\
\hline $\begin{array}{l}\text { L. Albenali } \\
\text { ir kiti, } 2016 \text { [25] }\end{array}$ & $\begin{array}{l}\text { Nustatyti geriamujų D vi- } \\
\text { tamino papildų terapinị } \\
\text { poveikị pacientams, sergan- } \\
\text { tiems atopiniu dermatitu bei } \\
\text { herpetine egzema, ịvertinant } \\
\text { rezultatus pagal SCORAD } \\
\text { indeksą ir antimikrobinio } \\
\text { peptido LL-37 pokytį odoje }\end{array}$ & $\begin{array}{l}\text { Eksperimentinis intervencinis klini- } \\
\text { kinis tyrimas. } \\
\text { Pacientams buvo skiriami geriamieji } \\
\text { D3 vit. papildai, priklausomai nuo D } \\
\text { vit. nepakankamumo lygio, bei pa- } \\
\text { pildomai } 6000 \mathrm{IU} / \mathrm{d} 1-12 \text { metu paci- } \\
\text { entams ir } 10000 \mathrm{IU} / \mathrm{d} 12-18 \text { metu pa- } \\
\text { cientams. Tyrimas truko } 2 \text { ménesius }\end{array}$ & $\begin{array}{l}\text { AD sergantys pacientai } \\
(\mathrm{n}=12) \text {. } \\
\text { Herpetine egzema ser- } \\
\text { gantys pacientai }(\mathrm{n}=35) . \\
\text { Amžius: } 1-18 \text { metų. } \\
\text { I klinikinį tyrimą itraukti } \\
\text { pacientai, kurių } \mathrm{D} \text { vit. } \\
\text { kiekis kraujo serume } \\
\text { buvo }<75 \mathrm{nmol} / 1\end{array}$ & $\begin{array}{l}\text { Tyrimo pabaigoje SCORAD indeksas } \\
\text { sumažejo } 42 \%(\mathrm{p}=0,001) \text {. Pastebėtas } \\
\text { statistiškai reikšmingas antimikrobi- } \\
\text { nio peptido LL-37 padidèjimas }\end{array}$ \\
\hline
\end{tabular}

naudojami atopinio dermatito gydymui.

3. Gydytojams būtu galima rekomenduoti patikrinti sunkiu, recidyvuojančiu atopiniu dermatitu sergančius pacientus dèl D vitamino deficito, o ji nustačius, koreguoti pagal patvirtintas šalies D vitamino stokos gydymo rekomendacijas.

4. Norint pateikti patikimas išvadas, reikia sukaupti daugiau mokslu pagrịstų ịrodymų, būtini daugiacentriai, didelès apimties, standartizuoti klinikiniai tyrimai, nagrinejjantys ryši tarp D vitamino ir atopinès egzemos.

\section{Literatūra}

1. Stanway A. Atopic dermatitis. 2021. https://dermnetnz.org/ topics/atopic-dermatitis/

2. Barbarot S, Auziere S, Gadkari A, Girolomoni G, Puig L, Simpson EL, et al. Epidemiology of atopic dermatitis in adults: Results from an international survey. Allergy 2018;73(6):1284-93. https://doi.org/10.1111/all.13401

3. D'Auria E, Banderali G, Barberi S, Gualandri L, Pietra B, Riva E, et al. Atopic dermatitis: recent insight on pathogenesis and novel therapeutic target. Asian Pac J Allergy Immunol 2016;34(2):98-108.

4. Palmer DJ. Vitamin D and the Development of Atopic Eczema. J Clin Med 2015 ;4(5):1036-50.

https://doi.org/10.3390/jcm4051036
6. Chiu C-Y, Huang S-Y, Peng Y-C, Tsai M-H, Hua M-C, Yao T-C, et al. Maternal vitamin $\mathrm{D}$ levels are inversely related to allergic sensitization and atopic diseases in early childhood. Pediatr Allergy Immunol 2015;26(4):337-43.

https://doi.org/10.1111/pai.12384

7. Su O, Bahalı AG, Demir AD, Ozkaya DB, Uzuner S, Dizman D, et al. The relationship between severity of disease and vitamin D levels in children with atopic dermatitis. Adv Dermatol Allergol Dermatol Alergol 2017;34(3):224-7. https://doi.org/10.5114/pdia.2017.66054

8. Cheon BR, Shin JE, Kim YJ, Shim JW, Kim DS, Jung HL, et al. Relationship between serum 25-hydroxyvitamin D and interleukin-31 levels, and the severity of atopic dermatitis in children. Korean J Pediatr 2015;58(3):96-101. https://doi.org/10.3345/kjp.2015.58.3.96

9. Eichenfield LF, Ellis CN, Mancini AJ, Paller AS, Simpson EL. Atopic dermatitis: epidemiology and pathogenesis update. Semin Cutan Med Surg 2012;31(3 Suppl):S3-5. https://doi.org/10.1016/j.sder.2012.07.002

10. Baeke F, Takiishi T, Korf H, Gysemans C, Mathieu C. Vitamin D: modulator of the immune system. Curr Opin Pharmacol 2010;10(4):482-96.

https://doi.org/10.1016/j.coph.2010.04.001

11. Quirk SK, Rainwater E, Shure AK, Agrawal DK. Vitamin D 
in Atopic Dermatitis, Chronic Urticaria and Allergic Contact Dermatitis. Expert Rev Clin Immunol 2016;12(8):839-47.

https://doi.org/10.1586/1744666X.2016.1171143

12. Kim MJ, Kim S-N, Lee YW, Choe YB, Ahn KJ. Vitamin D Status and Efficacy of Vitamin D Supplementation in Atopic Dermatitis: A Systematic Review and Meta-Analysis. Nutrients 2016;8(12):789.

https://doi.org/10.3390/nu8120789

13. Kuo I-H, Yoshida T, De Benedetto A, Beck LA. The cutaneous innate immune response in patients with atopic dermatitis. J Allergy Clin Immunol 2013;131(2):266-78.

https://doi.org/10.1016/j.jaci.2012.12.1563

14. Bikle DD. Vitamin D Metabolism and Function in the Skin. Mol Cell Endocrinol. 2011;347(1-2):80-9.

https://doi.org/10.1016/j.mce.2011.05.017

15. Muehleisen B, Gallo RL. Vitamin D in allergic disease: shedding light on a complex problem. J Allergy Clin Immunol 2013;131(2):324-9.

https://doi.org/10.1016/j.jaci.2012.12.1562

16. Hattangdi-Haridas SR, Lanham-New SA, Hing Sang Wong W, Hok Kung Ho M, Darling AL. Vitamin D Deficiency and Effects of Vitamin D Supplementation on Disease Severity in Patients with Atopic Dermatitis: A Systematic Review and Meta-Analysis in Adults and Children. Nutrients 2019;11(8). https:/www.ncbi.nlm.nih.gov/pmc/articles/PMC6722944/ https://doi.org/10.3390/nu11081854

17. Patrizi A, Raone B, Ravaioli GM. Management of atopic dermatitis: safety and efficacy of phototherapy. Clin Cosmet Investig Dermatol 2015;8:511-20. https://doi.org/10.2147/CCID.S87987

18. Mansour NO, Mohamed AA, Hussein M, Eldemiry E, Daifalla A, Hassanin S, et al. The impact of vitamin D supplementation as an adjuvant therapy on clinical outcomes in patients with severe atopic dermatitis: A randomized controlled trial. Pharmacol Res Perspect 2020;8(6). https://www.ncbi.nlm.nih.gov/ pmc/articles/PMC7609811/

https://doi.org/10.1002/prp2.679

19. Lara-Corrales I, Huang CM, Parkin PC, Rubio-Gomez GA, Posso-De Los Rios CJ, Maguire J, et al. Vitamin D Level and Supplementation in Pediatric Atopic Dermatitis: A Randomized Controlled Trial. J Cutan Med Surg. 2019;23(1):44-9. https://doi.org/10.1177/1203475418805744

20. Udompataikul M, Huajai S, Chalermchai T, Taweechotipatr M, Kamanamool N. The Effects of Oral Vitamin D Supplement on Atopic Dermatitis: A Clinical Trial with Staphylococcus aureus Colonization Determination. J Med Assoc Thail Chotmaihet Thangphaet. 2015;98 Suppl 9:S23-30.

21. Filippo PD, Scaparrotta A, Rapino D, Cingolani A, Attanasi M, Petrosino MI, et al. Vitamin D Supplementation Modulates the
Immune System and Improves Atopic Dermatitis in Children. Int Arch Allergy Immunol 2015;166(2):91-6.

https://doi.org/10.1159/000371350

22. Sánchez-Armendáriz K, García-Gil A, Romero CA, Contreras-Ruiz J, Karam-Orante M, Balcazar-Antonio D, et al. Oral vitamin D3 $5000 \mathrm{IU} /$ day as an adjuvant in the treatment of atopic dermatitis: a randomized control trial. Int J Dermatol 2018;57(12):1516-20.

https://doi.org/10.1111/ijd.14220

23. Tsotra K, Garoufi A, Kossiva L, Gourgiotis D, Tsoukatou T, Katsantoni E, et al. The impact of vitamin D supplementation on serum cathelicidin levels and the clinical course of atopic dermatitis in children. Minerva Pediatr 2017.

24. Imoto RR, Uber M, Abagge KT, Lima MN, Rosário NA, Carvalho VO de. Vitamin D supplementation and severity of atopic dermatitis: pre-post assessment. Allergol Immunopathol (Madr) 2021;49(2):66-71.

https://doi.org/10.15586/aei.v49i2.67

25. Albenali LH, Danby S, Moustafa M, Brown K, Chittock J, Shackley F, et al. Vitamin D and antimicrobial peptide levels in patients with atopic dermatitis and atopic dermatitis complicated by eczema herpeticum: A pilot study. J Allergy Clin Immunol $2016 ; 138(6): 1715-1719 . e 4$.

https://doi.org/10.1016/j.jaci.2016.05.039

\section{THE CLINICAL EFFECTS OF ORAL VITAMIN D SUPPLEMENTATION IN PATIENTS WITH ATOPIC ECZEMA \\ E. Petruškevičiūtė, I. Kisielienè}

Keywords: atopic dermatitis, vitamin D supplementation, atopic eczema, vitamin D.

Summary

This article aims to review the newest clinical trials and systematic reviews with meta-analysis about the clinical effects of oral vitamin D supplementation in patients with atopic eczema. The information was collected using PubMed and UpToDate databases. Clinical trials highlighted a possible link between the severity of atopic dermatitis and hypovitaminosis D. Patients diagnosed with atopic eczema tend to have lower vitamin D levels in comparison with healthy controls. Some publications showed that insufficient level of vitamin D in early childhood leads to atopic diseases, such as eczema or asthma. Based on the newest reports, vitamin D supplementation might effectively reduce symptoms of atopic dermatitis and prevent from S.aureus colonisation in the skin. Therefore, there are controversial reports about this topic, so more high-quality clinical trials are required to make reliable conclusions.

Correspondence to: evelinapetruskeviciute@gmail.com

Gauta 2021-09-07 